\title{
Smart Contract Innovation and Blockchain-Based Tokenization in Higher Education
}

\author{
I Ketut Gunawan ${ }^{1 *}$, Ninda Lutfiani ${ }^{2}$, Qurotul Aini $^{3}$, Fitria Marwati Suryaman ${ }^{4}$, Abas \\ Sunarya ${ }^{5}$ D \\ 1,2,3,4,5 Universitas Raharja, Tangerang, Indonesia
}

\section{A R T I C L E I N F O}

Article history:

Received September 10, 2021

Revised September 11, 2021

Accepted October 12, 2021

Available online November 25, 2021

Kata Kunci:

Blockchain, Inovasi, Kontrak Cerdas, Tokenisasi

Keywords:

Blockchain, Innovation, Smart

Contract, Tokenization

DOI:

https://dx.doi.org/10.23887/jet.v5i4.406 65

\begin{abstract}
A B S T R A K
Blockchain yang mencakup fitur kontrak pintar dan tokenisasi merupakan teknologi terbaru di dunia khususnya Indonesia. Smart contract dan tokenisasi sangat memudahkan pengguna dan dapat menjaga keamanan data yang valid, namun masih banyak perguruan tinggi yang belum menerapkan sistem tersebut sehingga harus melibatkan banyak pihak dan biaya. Permasalahan yang diambil pada penelitian ini yaitu proses pembayaran transaksi seperti kredit dan pengolahan data yang rentan dengan kebocoran data secara ilegal. Penelitian ini bertujuan untuk mengembangkan sistem kontrak pintar dan tokenisasi blockchain di perguruan tinggi pada proses transaksi pembayaran. Metode yang digunakan dalam penelitian ini adalah analisis literatur review dan metode testing. Implementasi kontrak cerdas dan tokenisasi dapat menggantikan pihak ketiga sebagai penjaga keamanan data transaksi dengan semua pengguna Blockchain memperhatikan dan memastikan integritas keseluruhan proses dan aktivitas tersebut. Hal ini tentunya dapat menghindari permasalahan yang muncul dari adanya pihak ketiga dalam proses transaksi. Sehingga dapat disimpulkan bahwa implementasi smart contract dan tokenisasi Blockchain dalam transaksi pembayaran menjadi solusi yang tepat untuk diterapkan dalam proses transaksi pembayaran pada perguruan tinggi.
\end{abstract}

\section{A B S T R A C T}

Blockchain which includes smart contract and tokenization features is the latest technology in the world, especially Indonesia. Smart contracts and tokenization make it very easy for users and can maintain valid data security, but there are still many universities that have not implemented the system so they have to involve many parties and costs. The problem taken in this study is the payment process for transactions such as credit and data processing that is vulnerable to illegal data leakage. This study aims to develop a smart contract system and blockchain tokenization in universities in the payment transaction process. The method used in this research is literature review analysis and testing method. The implementation of smart contracts and tokenization can replace third parties as security guards of transaction data with all Blockchain users paying attention and ensuring the integrity of the entire process and activity. This of course can avoid problems that arise from the presence of third parties in the transaction process. So it can be concluded that the implementation of smart contracts and Blockchain tokenization in payment transactions is the right solution to be applied in the payment transaction process at universities.

This is an open access article under the CC BY-SA license. Copyright @ 2021 by Author. Published by Universitas Pendidikan Ganesha.

\section{INTRODUCTION}

Education is one of the essential factors to advance a nation. Through good education, new things are obtained to be used to create quality human resources (Buchner et al., 2010; Muhamad Nova, 2017). If a nation has quality human resources, of course, it can build its nation to be more (Fahmy et al., 2015; Yunita \& Maisarah, 2020). Therefore, every nation should have a good and quality education. Education must be prioritized because students have various potentials in themselves (Saputro, 2020). Learning will be more meaningful if students experience what they learn, not know it. Education is very much needed in the survival and welfare of a person's life, even in the welfare of a nation (Ale et al., 2017; Buchanan et al., 2019; Gishti, 2018). It causes education to be adapted to science and technology. The development of information and communication technology is increasingly affecting human life. Along with its development, Indonesian people are starting to recognize the internet (Loh \& Kanai, 2016; Muflih et al., 2021; Okoduwa et al., 2018). People can access information easily and quickly (Ho \& Ismawan Prasetia Devi, 2020; Wijaya et al., 2021). Changes in 
technology, in general, have influenced the development of education. In addition to impacting the world of education, technology also affects the world of work, especially in preparing workers who are learning to master new work skills (Fitri \& Putro, 2021; Lapitan et al., 2021). The role of technology in education is proliferating. The need for technology is indispensable in the current era of globalization. One of the progress of an educational institution can be seen from how the school utilizes Information and Communication Technology (ICT) according to the needs and benefits optimally (Al-Fraihat et al., 2020; Rusli et al., 2020). Blockchain, which includes smart contract and tokenization features, is the latest technology in Indonesia and the world (Huang et al., 2019; Sayeed et al., 2020). A smart contract is a contract that is carried out partially or without human interaction that is automated in escrow so that it can make it easier for users. In short, a smart contract is a set of programs that are self-verifying, self-executing, and tamper-resistant (Rahardja, Lutfiani, Lestari, et al., 2019; Rahardja et al., 2021). While blockchain tokenization is the process of various forms of assets that have been converted into tokens that can be stored, transferred and recorded on the blockchain. Blockchain technology is mature enough to support the implementation of a complete and functional platform for asset tokenization. This introduces new opportunities for cost savings in financial services, especially in the post-trade cycle (Bünz et al., 2020; Mohanta et al., 2018).

Although smart contracts and tokenization make it very easy for users and can maintain valid data security, there are still many universities that have not implemented the system, so they have to involve many parties and costs (Wang et al., 2018; Zou et al., 2019). The process of implementing education globally has not changed with the times. Various problems currently faced by education service providers, in this case, call it the problem of authentication and verification of certificates (Febriyanto et al., 2019; Rahardja \& Lutfiani, 2020). which are both micro and macro outputs of a learning process (Giancaspro, 2017; Zhang et al., 2018). The combination of knowledge between the field of education and blockchain technology will create a new revolution in the education industry which is felt to be stagnant and incompatible with current developments (X. Chen, 2018; Rahardja, Lutfiani, \& Amelia, 2019). With blockchain technology, transactions can be carried out in a decentralized manner. As a result, blockchain can greatly save costs and increase efficiency (Karamitsos et al., 2018; Macrinici et al., 2018). The important thing that motivates us to conduct this research is the problems that are taken in the research, namely the payment processing transactions such as credit and data processing that are vulnerable to illegal data leakage (Lutfiani et al., 2020; Raharja et al., 2019). The urgency of this study is to analyze online payment transactions at universities as an innovation of manual transaction systems in preventing illegal data leakage (Nurhaeni et al., 2021; Yusup et al., 2019). This study aims to develop a smart contract system and blockchain tokenization in universities in processing payment transactions and guaranteeing data security legally without involving third parties (Agustin et al., 2020; Rahardja, Hidayanto, Hariguna, et al., 2019). Therefore, the application of Blockchain technology is to provide security for online payment transactions in the digital 4.0 era so that it is not misused by irresponsible parties (Dolgui et al., 2020; Khatoon, 2020) .

\section{METHOD}

A literature review contains theories, findings and research materials to be used as the main basis for new research. Literature reviews are at the top of the evidence hierarchy. This shows that literature review is a technique to prove or approach a particular problem or it can be said that literature review is a scientific process that produces output in the form of reports intended to conduct scientific research or focus a research. The description in the literature review is directed at developing a clear and accurate framework for solving the problems that have been formulated in the problem (Parizi \& Dehghantanha, 2018; Yuan et al., 2018).

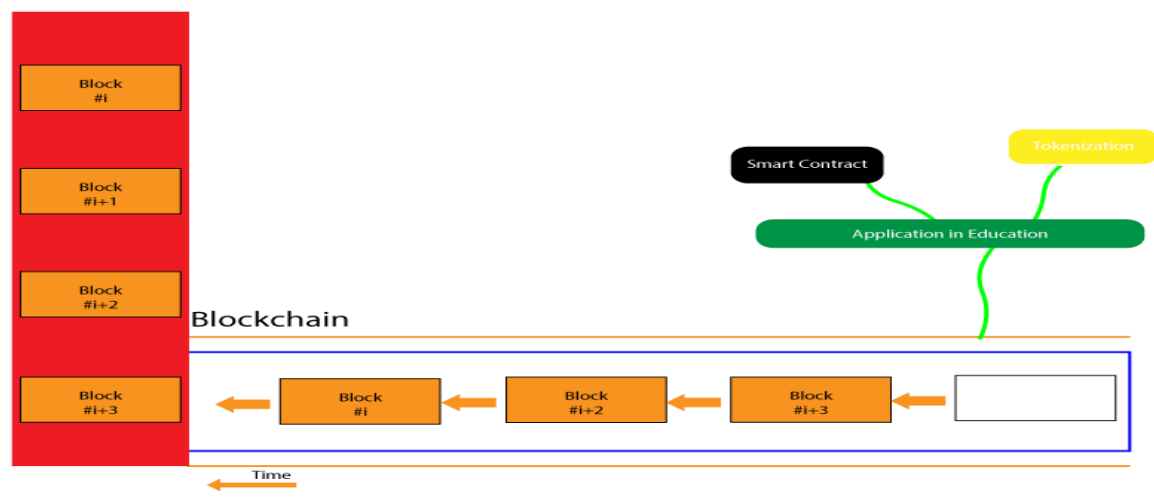

Figure 1. Blockchain Working System 
From Figure 1 above there are 4 (four) stages of blockchain in the world of education, namely: In this blockchain, all digital transactions are recorded by users according to their structure, where individual records are called blocks and then linked to a list called chain. This column explains that in the world of education blockchain has the advantage of helping students or their users to avoid the risk of theft or loss of digital data. Part of the smart contract or smart contract has an account balance, personal storage and executable code. The status is stored on the blockchain and will then be updated every time the contract is executed. This tokenization will be processed in various forms of conversion into tokens so that they are easily transferred, stored, and then recorded on the blockchain, so that the converted tokens can be transferred and manipulated. This study discusses blockchain technology which has gained great momentum in recent years. Blockchain is a distributed ledger that allows parties who do not fully trust each other to maintain a global set of states. The method used is a state of the art survey, with a focus on private blockchains (which parties are authenticated) (Casado-Vara et al., 2018; Chang et al., 2019). Based on the conclusions obtained, the smart contract work/workflow system and blockchain-based tokenization have very significant benefits for the world of education, especially in universities. Because it is easy to understand and has a high level of data security, it plays an important role in building the quality of higher education in Indonesia to be more advanced (Perez \& Livshits, 2019; Zhou et al., 2018).

Table1. Testing Security Smart Contract And Tokenization

\begin{tabular}{|c|c|c|c|c|}
\hline No. & Security & Related Work & Keywords & $\begin{array}{c}\text { Open Source } \\
\text { Tool }\end{array}$ \\
\hline \multirow{2}{*}{1.} & \multirow{2}{*}{ Design Principle } & General Philosophy & $\begin{array}{l}\text { Prepare for failure, Rollout Carefully, Keep } \\
\text { Contract Simple }\end{array}$ & No \\
\hline & & Security Guideline & $\begin{array}{l}\text { Check-effects-interaction, Emergency stop, } \\
\text { Mutex }\end{array}$ & No \\
\hline \multirow{2}{*}{2.} & \multirow[t]{2}{*}{ Design Pattern } & Security Pattern & Authorization, Time Constraint, Oracle & No \\
\hline & & Empirical Analysis & Finite state machine & No \\
\hline \multirow{2}{*}{3.} & Security Modeling & FSolidM & Procedure languages & Yes \\
\hline & & Logic-Based Approach & Code Generator & No \\
\hline
\end{tabular}

Blockchain features, including decentralization, immutability, transparency and auditability, make transactions more secure and tamper proof. Apart from cryptocurrencies, blockchain technology can be used in financial and social services, risk management, healthcare facilities, and so on. The method used is a comparative study of blockchain trade offs (Y.-H. Chen et al., 2018; Saraswati et al., 2021). The emergence of blockchain technology has created a number of potential innovations in dealing with business activities in various industries. However, few studies address the potential impact of blockchain technology from a business process reengineering perspective. This study focuses on the feasibility and early adoption of supply chain processes. The steps used are the comparative analysis framework (Li et al., 2019; Thomas et al., 2019). Blockchain-based sharing services can contribute to smart cities based on a conceptual framework. We hope to stimulate interest in theory and practice to encourage discussion in this area. The method used is relying on previous literature, this paper proposes a conceptual framework with three dimensions: (1) people, (2) technology, and (3) organization, and explores a set of fundamental factors that make smart cities from a shared economic perspective (Pee et al., 2019; Praitheeshan et al., 2019). It is safe that from 30 people there are 26 people who are the benchmark for the minimum data sample used in security system research in smart contract implementation and blockchain tokenization in payment transactions (Liu et al., 2019; Wu et al., 2018).

In this paper, the author conducts a survey of Blockchain applications using Blockchain technology and the challenges it faces. The technology that has had the most impact on our lifestyle in the last decade is Blockchain. The word that often comes up when talking about Blockchain is Bitcoin. Many people still confuse Blockchain with Bitcoin; However, the two are not the same. Bitcoin is just one of many applications that use Blockchain technology (He et al., 2020; Ryan, 2017). This study examines smart contracts that are not sintermedied and generally transparent, offering the promise of increased commercial efficiency, lower transaction and legal fees, and anonymous transactions. The business world is actively investigating the use of blockchain technology for various commercial purposes. While questions surround the security and reliability of this technology, and its negative impact on traditional intermediaries, there are equally important concerns that smart contracts will face. considerable difficulty to adapt. the current legal framework governing crossjurisdictional contracts. This article discusses potential issues with law enforcement and practices that arise from the use of smart contracts in civil law and common law jurisdictions. The steps used are case studies. 


\section{RESULT AND DISCUSSION}

\section{Result}

This research shows that blockchain-based smart contract and tokenization work systems are very much needed by Indonesian universities, especially in conducting payment transactions. Due to the high level of data security, this system is very suitable for use by students when they want to store data, even transactions. Blockchain discourse is currently an interesting topic to discuss (Agustin et al., 2020; Gunawan et al., 2021). As a new system, of course not everyone understands this blockchain system, moreover the system is still developing, especially in relation to its utilization (Kim et al., 2018; Sato \& Himura, 2018). Figure 2 above is a workflow or work system for blockchain-based tokenization. Broadly speaking, the tokenization process eliminates the connection between transactions and sensitive data thereby minimizing data theft (Eka et al., 2021; Sayeed et al., 2020). There are 16 (sixteen) digit numbers in the original data or main credit number which can only be known by the owner then the system will process the original data number with the token value in the token space to be safe, then after the original number is synchronized then the number that has been tokenized for used as a transaction. For example, tokenization in banking protects cardholder data (Rahardja, Lutfiani, \& Juniar, 2019). When we process payments using tokens stored in our system, only the original (authentic) credit card tokenization system can exchange the tokens for the appropriate Primary Account Number (PAN) and send it to the payment processor for authorization. The description of the tokenization working system above can be concluded that tokenization has benefits, namely a very high level of security and data protection, so users don't have to worry about making transactions (Hahn et al., 2017; Younus \& Raju, 2021).

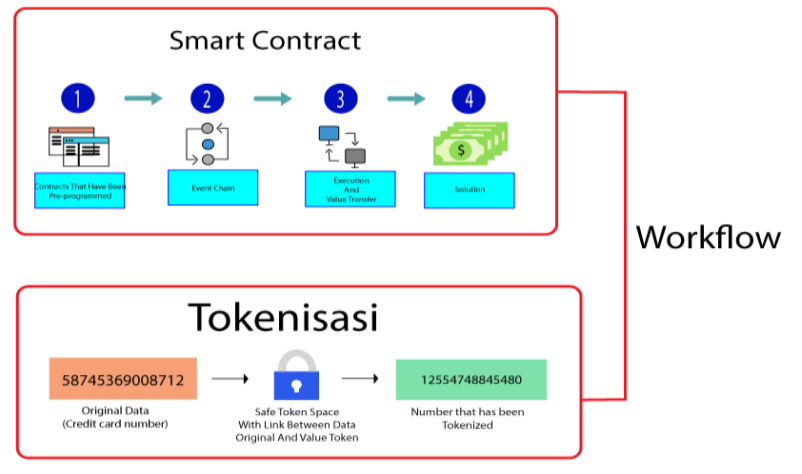

Figure 2. Blockchain Tokenization Work System

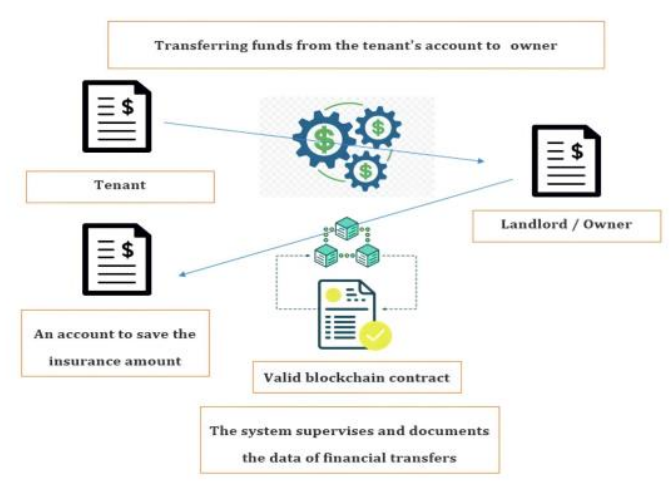

Figure 3. Payment Transaction Process

Blockchain has a way of starting when a block stores new data whereas the blockchain itself has two types of transaction records and blocks. Uniquely, each block contains a cryptographic hash to form a network. Network users, spread all over the world and are not tied to each other, either in a personal or professional bond, and instantly receive the latest transaction data. They run the data through a cryptographic algorithm, which generates a "hash", a string of numbers and letters that serves to verify the validity of the information, but does not reveal information from the data itself. The function of a cryptographic hash is to take data from the original block and convert it into a compact string. This string becomes a detection alarm if potential sabotage is found. Blockchain technology is also decentralized, so no single authority has complete control, so it is fragmented on every computer that has been installed with special software (McCorry et al., 2017; Zhuang et al., 2020).

Blockchain is also referred to as a centralized, public or general distributed ledger which is used to record transactions across multiple computers so that records cannot be changed retroactively without changing the entire block afterwards as well as the consensus in the network. In its application, blockchain can be used as a general potential, namely as a long-term operating business model, land registration, the big four means accepting bitcoin as a medium of payment for all consulting services, smart contracts or blockchain-based smart contracts. Contracts that can be executed partially or without interaction. people, non-profit organizations, centralized networks, governments and national currencies, banks, financial companies, and many other uses. Some of the applications of blockchain technology include digital currency, smart contracts and supply chain management. The types of blockchains themselves are divided into three parts, namely public blockchains where this type of blockchain has absolutely no access restrictions, meaning that anyone with internet access can send transactions and become validators, both private blockchains or commonly known as private blockchains are blockchains that must have permission by the owner of the network administrator access to participants and validators is restricted, and the last one is consortium or semi-decentralized blockchain is a type of blockchain which must also have permission but not one organization but from several companies that control it. Since 
blockchain is one of the core technologies in the FinTech (Financial Technology) industry, users are very concerned about its security. Several security vulnerabilities and attacks were recently reported. Loi et al. found that 8,833 of the 19,366 Ethereum contracts were vulnerable.

\section{Discussion}

In the world of education, the way blockchain works is permanent, transparent, and easy to track which allows students to view all proof of transactions accurately. Each update is a new "block" added at the end of the "chain". The discovery of new technologies and the expansion of connections play an important role in aspects of daily life. With the development of today's technology, a new education system has been developed but it has problems related to the learning process, payment, student trust. The protocol governs how new posts or entries are initiated, validated, recorded, and distributed so that their owners don't have to bother with transactions. With the advent of blockchain, cryptology can replace third parties as trust custodians with all blockchain users paying attention and ensuring the integrity of all processes and activities (Asgaonkar \& Krishnamachari, 2019; Yu et al., 2017). Blockchain itself has the potential to transform education as it helps improve old data management models and is extremely beneficial for students and institutions providing education.
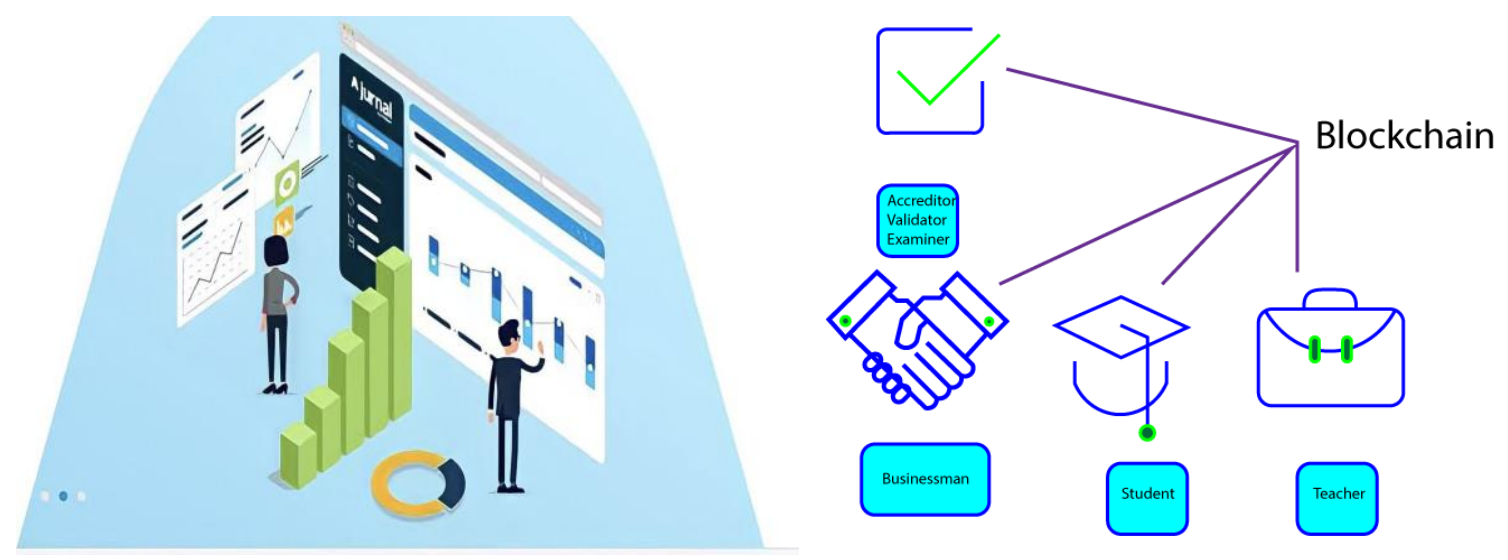

Figure 5. Blockchain Work System in the World of Education

The working system of smart contracts Blockchain-based and tokenization is very much needed by the Indonesian education sector, especially in higher education, because it can be a definite answer to existing problems, namely the payment process for transactions such as credit and data processing. The protocol governs how edits or new entries are initiated, validated, recorded, and distributed so that the owner does not have to go through the hassle of making transactions. With the use of Blockchain, cryptology can replace third parties as trustees with all Blockchain users paying attention and ensuring the integrity of the entire process and activity. This of course can avoid problems that arise from the presence of a 3 (three) party in the transaction process. Due to its nature that has a high level of data security, this system is very suitable if used by students when they want to store data and even transactions. Blockchain discourse is currently an interesting topic to discuss. As a new system, of course, not everyone understands this Blockchain system, moreover the system is still growing, especially related to its use (Lu et al., 2021; Sato \& Himura, 2018).

\section{CONCLUSION}

So it can be concluded that innovation smart contract and tokenization is the right solution to be applied for payment transactions. Because with the existence of smart contracts and blockchain-based tokenization, there is no need to worry about data leakage, data theft and digital data manipulation because the very high level of data security makes the risk of data leakage, data theft and data manipulation very minimal. To improve the quality or quality of Indonesian education, especially universities, to be better than before and to avoid leakage of online transaction data, data theft and digital data manipulation, it is better if institutions engaged in education are required to use this smart contract Blockchain-based and tokenization system. So that it makes students or users not worry when storing data digitally. This research has limitations, namely it only focuses on smart contracts and tokenization, for further research it is better to expand the topic of various kinds of Blockchain applications other than smart contracts and tokenization in the world of education 


\section{REFERENCES}

Agustin, F., Aini, Q., Khoirunisa, A., \& Nabila, E. A. (2020). Utilization of Blockchain Technology for Management E-Certificate Open Journal System. Aptisi Transactions on Management (ATM), 4(2), 134-139. https://doi.org/10.33050/atm.v4i2.1293.

Al-Fraihat, D., Joy, M., Masa'deh, R., \& Sinclair, J. (2020). Evaluating E-learning systems success: An empirical study. Computers in Human Behavior, 102, 67-86. https://doi.org/10.1016/j.chb.2019.08.004.

Ale, K., Loh, Y. A. C., \& Chib, A. (2017). Contextualized-OLPC education project in rural India: measuring learning impact and mediation of computer self-efficacy. Educational Technology Research and Development, 65(3), 769-794. https://doi.org/10.1007/s11423-017-9517-2.

Asgaonkar, A., \& Krishnamachari, B. (2019). Solving the buyer and seller's dilemma: A dual-deposit escrow smart contract for provably cheat-proof delivery and payment for a digital good without a trusted mediator. 2019 IEEE International Conference on Blockchain and Cryptocurrency (ICBC), 262-267.

Buchanan, J., Pressick-Kilborn, K., \& Maher, D. (2019). Promoting environmental education for primary schoolaged students using digital technologies. Eurasia Journal of Mathematics, Science and Technology Education, 15(2). https://doi.org/10.29333/ejmste/100639.

Buchner, D., Snelling, A., \& Cohen, M. (2010). Spa-related education and training. In Understanding the Global Spa Industry (2nd ed., pp. 394-413). Taylor and Francis. https://doi.org/10.4324/9780080879161-35.

Bünz, B., Agrawal, S., Zamani, M., \& Boneh, D. (2020). Zether: Towards privacy in a smart contract world. International Conference on Financial Cryptography and Data Security, 423-443. http://dx.doi.org/10.1007/978-3-030-51280-4_23.

Casado-Vara, R., González-Briones, A., Prieto, J., \& Corchado, J. M. (2018). Smart contract for monitoring and control of logistics activities: Pharmaceutical utilities case study. The 13th International Conference on Soft Computing Models in Industrial and Environmental Applications, 509-517. http://dx.doi.org/10.1007/978-3-319-94120-2_49.

Chang, S. E., Chen, Y.-C., \& Lu, M.-F. (2019). Supply chain re-engineering using blockchain technology: A case of smart contract based tracking process. Technological Forecasting and Social Change, 144, 111. https://doi.org/10.1016/j.techfore.2019.03.015.

Chen, X. (2018). Blockchain challenges and opportunities : a survey Zibin Zheng and Shaoan Xie Hong-Ning Dai Huaimin Wang. IEEE International Symposium on High Performance Distributed Computing, Proceedings, 14(4), 352-375. http://dx.doi.org/10.1504/IJWGS.2018.095647.

Chen, Y.-H., Chen, S.-H., \& Lin, I.-C. (2018). Blockchain based smart contract for bidding system. 2018 IEEE International Conference on Applied System Invention (ICASI), 208-211. https://doi.org/10.1109/ICASI.2018.8394569.

Dolgui, A., Ivanov, D., Potryasaev, S., Sokolov, B., Ivanova, M., \& Werner, F. (2020). Blockchain-oriented dynamic modelling of smart contract design and execution in the supply chain. International Journal of Production Research, 58(7), 2184-2199. https://doi.org/10.1080/00207543.2019.1627439.

Eka, C., Santoso, N. P. L., Amelia, S., \& Devana, V. T. (2021). Pelatihan Software Editing Bagi Mahasiswa Pada Universitas Raharja. ADI Pengabdian Kepada Masyarakat, 1(2), 60-65. https://doi.org/10.34306/adimas.v1i2.442.

Fahmy, R., Bachtiar, N., Rahim, R., \& Malik, M. (2015). Measuring Student Perceptions to Personal Characters Building in Education: An Indonesian Case in Implementing New Curriculum in High School. Procedia - Social and Behavioral Sciences, 211. https://doi.org/10.1016/j.sbspro.2015.11.112.

Febriyanto, E., Rahardja, U., Faturahman, A., \& Lutfiani, N. (2019). Sistem Verifikasi Sertifikat Menggunakan Qrcode Pada Central Event Information. 18(1), 50-63. https://doi.org/10.33633/tc.v18i1.2078.

Fitri, Y., \& Putro, N. H. P. S. (2021). EFL Teachers' Perception of the Effectiveness of ICT-ELT Integration During the COVID-19 Pandemic. Proceedings of the International Conference on Educational Sciences and Teacher Profession (ICETeP 2020), 532(532), https://doi.org/10.2991/assehr.k.210227.086.

Giancaspro, M. (2017). Is a 'smart contract'really a smart idea? Insights from a legal perspective. Computer Law \& Security Review, 33(6), 825-835. https://doi.org/10.1016/j.clsr.2017.05.007.

Gishti, E. (Shehi). (2018). Social Partnership in Vocational Education and Training in Albania. European Journal of Education, 1(3), 163-169. https://doi.org/10.26417/ejed.v1i3.p163-169.

Gunawan, I. K., Sukmana, H. T., \& Ardianto, A. Y. (2021). Blockchain Technology as A Media for Sharing Information that Generates User Access Rights and Incentives. Blockchain Frontier Technology, 1(01), 44-55. https://journal.pandawan.id/b-front/article/view/2.

Hahn, A., Singh, R., Liu, C.-C., \& Chen, S. (2017). Smart contract-based campus demonstration of decentralized transactive energy auctions. 2017 IEEE Power \& Energy Society Innovative Smart Grid Technologies Conference (ISGT), 1-5. https://doi.org/10.1109/ISGT.2017.8086092. 
He, N., Wu, L., Wang, H., Guo, Y., \& Jiang, X. (2020). Characterizing code clones in the ethereum smart contract ecosystem. International Conference on Financial Cryptography and Data Security, 654-675. https://arxiv.org/abs/1905.00272.

Ho, L., \& Ismawan Prasetia Devi. (2020). A New trend in understanding students' interest in learning science: microetnography. Integrated Science Education Journal (ISEJ), 1(2), $62-66$. https://doi.org/10.37251/isej.v1i2.72.

Huang, Y., Bian, Y., Li, R., Zhao, J. L., \& Shi, P. (2019). Smart contract security: A software lifecycle perspective. IEEE Access, 7, 150184-150202. https://doi.org/10.1109/ACCESS.2019.2946988.

Karamitsos, I., Papadaki, M., \& Al Barghuthi, N. B. (2018). Design of the blockchain smart contract: A use case for real estate. Journal of Information Security, 9(03), 177. http://dx.doi.org/10.4236/jis.2018.93013.

Khatoon, A. (2020). A blockchain-based smart contract system for healthcare management. Electronics, 9(1), 94.

Kim, M., Hilton, B., Burks, Z., \& Reyes, J. (2018). Integrating blockchain, smart contract-tokens, and IoT to design a food traceability solution. 2018 IEEE 9th Annual Information Technology, Electronics and $\begin{array}{llll}\text { Mobile Communication } & \text { Conference } & \text { 335-340. }\end{array}$ https://doi.org/10.1109/IEMCON.2018.8615007.

Lapitan, L. D., Tiangco, C. E., Sumalinog, D. A. G., Sabarillo, N. S., \& Diaz, J. M. (2021). An effective blended online teaching and learning strategy during the COVID-19 pandemic. Education for Chemical Engineers, 35(May 2020), 116-131. https://doi.org/10.1016/j.ece.2021.01.012.

Li, Y., Yang, W., He, P., Chen, C., \& Wang, X. (2019). Design and management of a distributed hybrid energy system through smart contract and blockchain. Applied Energy, 248, 390-405. https://doi.org/10.1016/j.apenergy.2019.04.132.

Liu, H., Zhang, Y., Zheng, S., \& Li, Y. (2019). Electric vehicle power trading mechanism based on blockchain and smart contract in V2G network. IEEE Access, 7, 160546-160558. https://doi.org/10.1109/ACCESS.2019.2951057.

Loh, K., \& Kanai, R. (2016). How has the Internet Reshaped Human Cognition? Neoruscientist, 1(1), 506-520. https://doi.org/10.1177/1073858415595005.

Lu, N., Wang, B., Zhang, Y., Shi, W., \& Esposito, C. (2021). NeuCheck: A more practical Ethereum smart contract security analysis tool. Software: Practice and Experience, 51(10), 2065-2084. https://doi.org/10.1002/spe.2745.

Lutfiani, N., Rahardja, U., Studi, P., Informasi, S., \& Raharja, U. (2020). Peran inkubator bisnis dalam membangun startup pada perguruan tinggi. 5(1), 77-89. https://doi.org/10.33633/jpeb.v5i1.2727.

Macrinici, D., Cartofeanu, C., \& Gao, S. (2018). Smart contract applications within blockchain technology: A systematic mapping study. Telematics and Informatics, 35(8), 2337-2354. https://doi.org/10.1016/j.tele.2018.10.004.

McCorry, P., Shahandashti, S. F., \& Hao, F. (2017). A smart contract for boardroom voting with maximum voter privacy. International Conference on Financial Cryptography and Data Security, 357-375. http://dx.doi.org/10.1007/978-3-319-70972-7_20.

Mohanta, B. K., Panda, S. S., \& Jena, D. (2018). An overview of smart contract and use cases in blockchain technology. 2018 9th International Conference on Computing, Communication and Networking Technologies (ICCCNT), 1-4. https://doi.org/10.1109/ICCCNT.2018.8494045.

Muflih, S., Abuhammad, S., Al-Azzam, S., Alzoubi, K. H., Muflih, M., \& Karasneh, R. (2021). Online learning for undergraduate health professional education during COVID-19: Jordanian medical students' attitudes and perceptions. Heliyon, 7(9), e08031. https://doi.org/10.1016/j.heliyon.2021.e08031.

Muhamad Nova. (2017). Character Education In Indonesia EFL Classroom Implementation and Obstacles. Jurnal Pendidikan Karakter, 7(2). https://doi.org/10.21831/jpk.v7i2.13650.

Nurhaeni, T., Lutfiani, N., Singh, A., Febriani, W., \& Hardini, M. (2021). The Value of Technological Developments Based on An Islamic Perspective. International Journal of Cyber and IT Service Management, 1(1), 1-13. https://iiast-journal.org/ijcitsm/index.php/IJCITSM/article/download/4/11.

Okoduwa, S. I. R., Abe, J. O., Samuel, B. I., Chris, A. O., Oladimeji, R. A., Idowu, O. O., \& Okoduwa, U. J. (2018). Attitudes, Perceptions, and Barriers to Research and Publishing Among Research and Teaching Staff in a Nigerian Research Institute. Frontiers in Research Metrics and Analytics, 3(September), 110. https://doi.org/10.3389/frma.2018.00026.

Parizi, R. M., \& Dehghantanha, A. (2018). Smart contract programming languages on blockchains: An empirical evaluation of usability and security. International Conference on Blockchain, 75-91. http://dx.doi.org/10.1007/978-3-319-94478-4_6.

Pee, S. J., Kang, E. S., Song, J. G., \& Jang, J. W. (2019). Blockchain based smart energy trading platform using smart contract. 2019 International Conference on Artificial Intelligence in Information and Communication (ICAIIC), 322-325. https://doi.org/10.1109/ICAIIC.2019.8668978. 
Perez, D., \& Livshits, B. (2019). Smart contract vulnerabilities: Does anyone care? ArXiv Preprint ArXiv:1902.06710, 1-15.

Praitheeshan, P., Pan, L., Yu, J., Liu, J., \& Doss, R. (2019). Security analysis methods on ethereum smart contract vulnerabilities: a survey. ArXiv Preprint ArXiv:1908.08605. https://arxiv.org/abs/1908.08605.

Rahardja, U., Hidayanto, A. N., Hariguna, T., \& Aini, Q. (2019). Design Framework on Tertiary Education System in Indonesia Using Blockchain Technology. 2019 7th International Conference on Cyber and IT Service Management, CITSM 2019, 5-8. https://doi.org/10.1109/CITSM47753.2019.8965380.

Rahardja, U., \& Lutfiani, N. (2020). The Strategy of Improving Project Management Using Indicator Measurement Factor Analysis (IMF) Method. Journal of Physics: Conference Series, 1477(3), 32023. http://dx.doi.org/10.1088/1742-6596/1477/3/032023.

Rahardja, U., Lutfiani, N., Aini, Q., \& Annisa, I. Y. (2021). The Potential Utilization of Blockchain Technology. 1(1), 57-67.

Rahardja, U., Lutfiani, N., \& Amelia, S. (2019). Creative Content Marketing In Scientific Publication Management In Industrial Era 4.0. Aptisi Transactions on Management (ATM), 3(2), 168-178. https://doi.org/10.33050/atm.v3i2.991.

Rahardja, U., Lutfiani, N., \& Juniar, H. L. (2019). Scientific Publication Management Transformation In Disruption Era. 3(2), 109-118. https://doi.org/10.33050/atm.v3i2.1008.

Rahardja, U., Lutfiani, N., Lestari, A. D., \& Manurung, E. B. P. (2019). Inovasi Perguruan Tinggi Raharja Dalam Era Disruptif Menggunakan Metodologi iLearning. Jurnal Ilmiah Teknologi Informasi Asia, 13(1), 23-34. https://jurnal.stmikasia.ac.id/index.php/jitika/article/view/298.

Raharja, U., Lutfiani, N., Handayani, I., \& Suryaman, F. M. (2019). Motivasi Belajar Mahasiswa Terhadap Metode Pembelajaran Online iLearning+ Pada Perguruan Tinggi. Sisfotenika, 9(2), 192. https://doi.org/10.30700/jst.v9i2.497.

Rusli, R., Rahman, A., \& Abdullah, H. (2020). Student perception data on online learning using heutagogy approach in the Faculty of Mathematics and Natural Sciences of Universitas Negeri Makassar, Indonesia. Data in Brief, 29, 105152. https://doi.org/10.1016/j.dib.2020.105152.

Ryan, P. A. (2017). Smart contract relations in e-commerce: legal implications of exchanges conducted on the blockchain. Technology Innovation Management Review. https://timreview.ca/article/1110.

Saputro, F. E. (2020). The Role Of Islamic Religious Education Teachers In Actualizing Tolerance Attitudes To Students. AL-ISHLAH: Jurnal Pendidikan, 12(2), 336-347. https://doi.org/10.35445/alishlah.v12i2.214.

Saraswati, M., Lutfiani, N., \& Ramadhan, T. (2021). Kolaborasi Integrasi Inkubator Bersama Perguruan Tinggi Sebagai Bentuk Pengabdian Terhadap Masyarakat Dalam Perkembangan Iptek. ADI Pengabdian Kepada Masyarakat, 1(2), 23-31. https://doi.org/10.34306/adimas.v1i2.429.

Sato, T., \& Himura, Y. (2018). Smart-contract based system operations for permissioned blockchain. 20189 th IFIP International Conference on New Technologies, Mobility and Security (NTMS), 1-6. https://doi.org/10.1109/NTMS.2018.8328745.

Sayeed, S., Marco-Gisbert, H., \& Caira, T. (2020). Smart contract: Attacks and protections. IEEE Access, 8, 24416-24427. https://doi.org/10.1109/ACCESS.2020.2970495.

Thomas, L., Zhou, Y., Long, C., Wu, J., \& Jenkins, N. (2019). A general form of smart contract for decentralized energy systems management. Nature Energy, 4(2), 140-149. https://www.nature.com/articles/s41560018-0317-7.

Wang, S., Yuan, Y., Wang, X., Li, J., Qin, R., \& Wang, F.-Y. (2018). An overview of smart contract: architecture, applications, and future trends. 2018 IEEE Intelligent Vehicles Symposium (IV), 108-113. https://doi.org/10.1109/IVS.2018.8500488.

Wijaya, H., Tari, E., Sumule, L., Weismann, I. T. J., \& Supartini, T. (2021). Online Learning Evaluation in Higher Education: Study Survey Method. Journal of Education Technology, 5(3), 401-408. https://doi.org/10.23887/jet.v5i3.35466.

Wu, S., Chen, Y., Wang, Q., Li, M., Wang, C., \& Luo, X. (2018). CReam: A smart contract enabled collusionresistant e-auction. IEEE Transactions on Information Forensics and Security, 14(7), 1687-1701. https://doi.org/10.1109/TIFS.2018.2883275.

Younus, A. M., \& Raju, V. (2021). Resilient Features of Organizational Culture in Implementation of Smart Contract Technology Blockchain In Iraqi Gas and Oil Companies. International Journal for Quality Research, 15(2), 435.

Yu, L., Tsai, W.-T., Li, G., Yao, Y., Hu, C., \& Deng, E. (2017). Smart-contract execution with concurrent block building. 2017 IEEE Symposium on Service-Oriented System Engineering (SOSE), 160-167. https://doi.org/10.1109/SOSE.2017.33.

Yuan, R., Xia, Y.-B., Chen, H.-B., Zang, B.-Y., \& Xie, J. (2018). Shadoweth: Private smart contract on public blockchain. Journal of Computer Science and Technology, 33(3), 542-556. https://link.springer.com/article/10.1007/s11390-018-1839-y. 
Yunita, W., \& Maisarah, I. (2020). Students ' Perception On Learning Language At The Graduate Program OF English Education Amids The Covid 19 Pandemic. Linguists: Journal of Linguistics and Language Teaching, 2069(6), 107-120. https://doi.org/10.29300/ling.v6i2.3718.

Yusup, M., Aini, Q., Apriani, D., \& Nursaputri, P. (2019). Pemanfaatan Teknologi Blockchain Pada Program Sertifikasi Dosen. SENSITIf: Seminar Nasional Sistem Informasi Dan Teknologi Informasi, 365-371. https://ejurnal.dipanegara.ac.id/index.php/sensitif/article/view/575.

Zhang, Y., Kasahara, S., Shen, Y., Jiang, X., \& Wan, J. (2018). Smart contract-based access control for the internet of things. IEEE Internet of Things Journal, 6(2), 1594-1605. https://doi.org/10.1109/JIOT.2018.2847705.

Zhou, E., Hua, S., Pi, B., Sun, J., Nomura, Y., Yamashita, K., \& Kurihara, H. (2018). Security assurance for smart contract. 2018 9th IFIP International Conference on New Technologies, Mobility and Security (NTMS), 1-5. https://doi.org/10.1109/NTMS.2018.8328743.

Zhuang, Y., Liu, Z., Qian, P., Liu, Q., Wang, X., \& He, Q. (2020). Smart Contract Vulnerability Detection using Graph Neural Network. IJCAI, 3283-3290. https://doi.org/10.24963/ijcai.2020/454.

Zou, W., Lo, D., Kochhar, P. S., Le, X.-B. D., Xia, X., Feng, Y., Chen, Z., \& Xu, B. (2019). Smart contract development: Challenges and opportunities. IEEE Transactions on Software Engineering. https://doi.org/10.1109/TSE.2019.2942301 davav. 